\title{
A Study of the 1668 Deungrok, Records of Celestial Phenomena from the Joseon Dynasty
}

\author{
Il-Seong $\mathrm{Nha}^{{ }^{\dagger}}$, Yoon Hong ${ }^{2}$, and Nami $\mathrm{Ahn}^{3}$ \\ ${ }^{1}$ Department of Astronomy, Yonsei University, Seoul 120-749, Korea \\ ${ }^{2}$ Korean Academy of Meteorology and Climate, Seoul 156-720, Korea \\ ${ }^{3}$ Academy of East Asian Studies, Sungkyunkwan University, Seoul 110-745, Korea
}

This paper will introduce and overview in general the Seongbyeon Deungrok issued by the Gwansang-gam, the Astronomical Board in the Joseon Dynasty of Korea. All the Chinese characters in the 1668 Seongbyeon Deungrok was deciphered at first and these were translated into Korean and English. With these translations and the word 'white vapor' in particular we discuss the nature of the main object in this Deungrok. Lastly, names of observers who engaged in the observations of this 1668 celestial, which are made as a by-product of this research, are introduced.

Keywords: comet, guest star, white vapor, phenomena, Seongbyeon Deungrok, Seungjeong-won Ilgi, Cheomseong-dae

\section{INTRODUCTION}

In the course of restoration in 2011 to its original form for the copy of 「the 1668 Seongbyeon Deungrok (康熙七年星變 謄錄)」, which has been kept by Nha Il-Seong since 1999, we first make an introduction to Seongbyeon Deungroks published by the Astronomical Board (Gwansang-gam, 觀 象監) of the Joseon Dynasty, 1392-1910, in order to know what kind of record this Seongbyeon Deungrok is. Then a summary to known Seongbyeon Deungroks and the copy of the 1668 Deungrok is presented. The recorded contents in this Deungrok has been deciphered, rewritten in Chinese characters, and translated to English in this paper. We point out that the record "white vapor" describes a too strange phenomenon to be a comet. It is interesting to know that an old expression of 'Cheomseong-dae (瞻星臺)' had been used in this Deongrok for their observing site in the North Gwangwha-bang (北部光化坊). We also present the titles and names of 12 observing staffs which were recovered by our study.

\section{SEONGBYEON CHOOKHOO DANJA (星變測候 單子) AND SEONGBYEON DEUNGROK (星變謄錄)}

In the Joseon Dynasty, the observing staffs at the Astronomical Board (Gwansang-gam) made a report on unusual celestial and terrestrial event on their day or night duty to the Royal Secretariat (Seungjeong-won) without delay early next morning (Nha 1978). The one-page report in this process was called Seongbyeon Chookhoo Danja (星變測候單子, Danja in short). The observers on duty at Cheomseong-dae worked in teams of three at normal times, with reinforcements of one or two people to make the team of four or five in a case of celestial event. If the observing staffs on duty observed an astronomical event (Seongbyeon, 星變), they wrote down their titles and names at the end of Danja before they submitted it to Seungjeong-won in the next morning. This was to make it clear that the report had been made in agreement of the observers. As a daily report, Danjas might have been cumulated to an enormous number over ages although it may depend on the duration of each event. Once the event ended, Gwansang-gam kept the original Danjas somewhere and made good copies of them

Received Jan 17, 2012 Revised Feb 2, 2012 Accepted Feb 24, 2012

†Corresponding Author

E-mail: : slisnha@chol.com

Tel: +82-2-337-9650 Fax: +82-2-333-9650 non-commercial use, distribution, and reproduction in any medium provided the original work is properly cited. (c) This is an open Access article distributed under the terms of the Creative Commons Attribution Non-Commercial License (http:// 
to build a book. Titles of these books included Chinese reign names and years in those periods, and the terms Seongbyeon Deungrok (星變謄錄), Cheonbyeon Deungrok (天變謄錄), or Gaekseong Deungrok (客星謄錄). Deungrok means a book and interestingly 'Seongbyeon (星變),' 'Cheonbyeon (天變),' or 'Gaekseong (客星)' comes before Deungrok to specify it. As an example of Chinese reign name and year, $\ulcorner$ The 7 th year of Kangxi Seongbyeon Deungrok (康熙七年星變謄錄)」 means that it is a Seongbyeon Deungrok made in the $7^{\text {th }}$ year of the reign of Kangxi in the Qing (淸) Dynasty of China. It should be noted that they used a Chinese reign name and year in spite that it is a book written by Gwansang-gam of Joseon for a celestial event in the $9^{\text {th }}$ year of the reign of Hyeonjong (1668), the 18th king in the Joseon Dynasty. There were close interchanges between the Astronomical Board Qintian-jian (欽天監) in China and Gwansang-gam (觀象監) in Joseon, and thus the same reign name was adopted in their convenience since the astronomical data exchanges were set up between the two institutions. It would be difficult to compare observing dates if different year counts are used for solar and lunar eclipses and for global events such as comets or novae (or guest stars). For example, writing the year of the celestial event in 1668 as 'Seventh year of Kangxi' in China on one hand but 'Nineth year of Hyeonjong' in Joseon on the other would have make it difficult to know that these two indicate the same event. A comparison table would have been necessary in this case. Besides, there are a number of cases that the same name was used by only one king in Korea but by several different kings through the Chinese history. For example, there was only one 'Sejong (世宗)' in Korea while four different kings used this name in China; 世宗 of Liao (遼), 世宗 of Jin (金),
世宗 of Ming (明), and 世宗 of Qing (淸). Considering these aspects, we may say that it was natural and reflecting an advanced form of international relationship for the two countries to have used the same reign name together. Most countries use A.D. for their dating system these days, but it was only about 110 years ago, in the 33th year of Gojong (高 宗), for Joseon to have adopted A.D., a result of the import of the Gregorian calendar.

The method of recording observed comets or guest stars in Danjas had already been established by Gwansanggam (Seong 1818), and it is surprisingly the same as the recording way by modern astronomers. Size of a Danja is not clear since there remains no real copy. Only the size of a Deungrok is known to be about $20 \times 34 \mathrm{~cm}$ by measuring three Seongbyeon Deungroks which are housed in the library of Yonsei University (Nha 1982). It should be noted that the Deungrok, which is a collection of Danja copies, is smaller than a Danja and bears the mark of being trimmed at its top and bottom in the process of bookbinding. Some characters in the top first line are partly or completely missing in some pages. Thus the vertical size of the Deungrok in Yonsei University must be larger than $35 \mathrm{~cm}$ at least.

\section{RECOVERY OF THREE SEONGBYEON DEUNGROK (星變謄錄)}

There are 8 books of Seongbyeong Deungrok known so far. They were found and reported in Japanese to the society by Wada Yuji (和田雄治) as shown in Table 1 (Wada 1917). The existence of Danjas became known from these Deungroks. In his article, Wada also introduced a photograph of the

Table 1. List of Seongbyeon Deungroks.

\begin{tabular}{|c|c|c|c|}
\hline No & Seongbyeon Deungrok & Year and month & Preserver \\
\hline 1 & $\begin{array}{l}\text { The 18th year of Shunzhi (順治) } \\
\text { Seongbyeon Deungrok (The 2nd year of Hyeonjong 顯宗) }\end{array}$ & February 1661 & Nha Il-Seong \\
\hline 2 & $\begin{array}{l}\text { The 3rd year of Kangxi (康熙) } \\
\text { Cheonbyeon Deungrok (The 5th year of Hyeonjong 顯宗) }\end{array}$ & November 1964 & Nha Il-Seong \\
\hline 3 & $\begin{array}{l}\text { The 7th year of Kangxi (康熙) } \\
\text { Seongbyeon Deungrok (The 9th year of Hyeonjong 顯宗) }\end{array}$ & March 1668 & Nha Il-Seong \\
\hline 4 & $\begin{array}{l}\text { The 34th year of Kangxi (康熙) } \\
\text { Seongbyeon Deungrok (The 21st year of Sookjong 肅宗) }\end{array}$ & November 1695 & Unknown \\
\hline 5 & $\begin{array}{l}\text { The 41st year of Kangxi (康熙) } \\
\text { Seongbyeon Deungrok (The 28th year of Sookjong 肅宗) }\end{array}$ & March 1702 & Unknown \\
\hline 6 & $\begin{array}{l}\text { The 1st year of Yongzheng (雍正) } \\
\text { Seongbyeong Deungrok (The 3rd year of Gyeongjong 景宗) }\end{array}$ & October 1723 & $\begin{array}{l}\text { Yonsei University } \\
\text { Library }\end{array}$ \\
\hline 7 & $\begin{array}{l}\text { The 24th year of Qianglong (乾隆) } \\
\text { Seongbyeong Deungrok (The 24th year of Youngjo 英租) }\end{array}$ & April 1759 & $\begin{array}{l}\text { Yonsei University } \\
\text { Library }\end{array}$ \\
\hline 8 & $\begin{array}{l}\text { The 24th year of Qianglong (乾隆) } \\
\text { Gaekseong Deungrok (The 24th year of Youngjo 英祖) }\end{array}$ & February 1760 & $\begin{array}{l}\text { Yonsei University } \\
\text { Library }\end{array}$ \\
\hline
\end{tabular}


1664 Kangxi (康熙) Cheonbyeon Deungrok, which contains a drawing of the comet and nearby constellations, and this is a copy of the Danja of the tenth day of the eleventh month (Wada 1917). Danjas as well as Deungroks of Joseon were introduced to the world in English by the efforts of W. Carl Rufus. He presented four photographs of the drawings of the 1664 comet to Transactions of the Korea Branch of the Royal Asiatic Society which was published in 1936 (Rufus 1936). Through this paper, European people were impressed by these drawings of the comet, which had been drawn before the photographic technique was invented, and at the same time Deungrok, the collections of Danjas, became widely known.

Over 40 years after the reports by Wada and Rufus on the eight Deungroks, the Korean society had not been aware even of the existence of the Deungrok. In the mid1970s some people in Korea noticed at last that the all of Deungroks were missing, but fortunately during their search the last three Deungroks (Nos. 6, 7 and 8 in Table 1) were recovered in early 1978 (Nha 1982, 1986). The library of Yonsei University purchased to possess them in no time and these three Deungroks have recently been registered as the cultural properties by the City of Seoul. This was such a gratifying event to the Korean society.

This recovery stimulated the society to search the remaining five Deungroks (Nos. 1 through 5 in Table 1), but there was no clue to the locations of those. In the meantime, a scholar in Japan sent copies of three Deungroks (Nos. 1, 2 and 3) to one of us (Nha) at the end of 1999. It should make it clear that these are not the originals. But, this additional recovery narrowed down the missing Deungroks to Nos. 4 and 5.

\section{THE CONTENTS OF THE 7TH YEAR OF KANGXI SEONGBYEON DEUNGROK (THE 1668 DEUNGROK)}

The title page and contents of the 1668 Deungrok are presented in Figs. 1-10. Except for the title page in Fig. 1, this Deungrok is a 9-page report on the observations of "white vapor" for four days from March 8, 1668 (the 26th day of the first month in the 9th year of Hyeonjong) to March 11 (the 26th day of the first month of Hyeonjong). Among those 9 pages, two pages have six Chinese characters 星變測候單 子, Seongbyeon Choohoo Danja on upper right corner. We present in this paper the English translations from what we deciphered and translated into Korean from the 9-page report (Korea Meteorological Administration 2012). All local times corresponding to the original measurements will be quoted on the 24-hour clock. It should be noted that when quoting the 60-day cycle, pinyin has been used rather than Hangul.

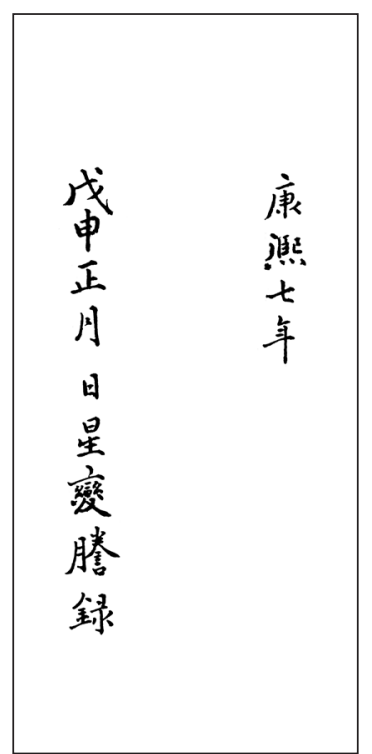

Fig. 1. Cover of the 1668 Deungrok (from Korea Meteorological Administration 2012).

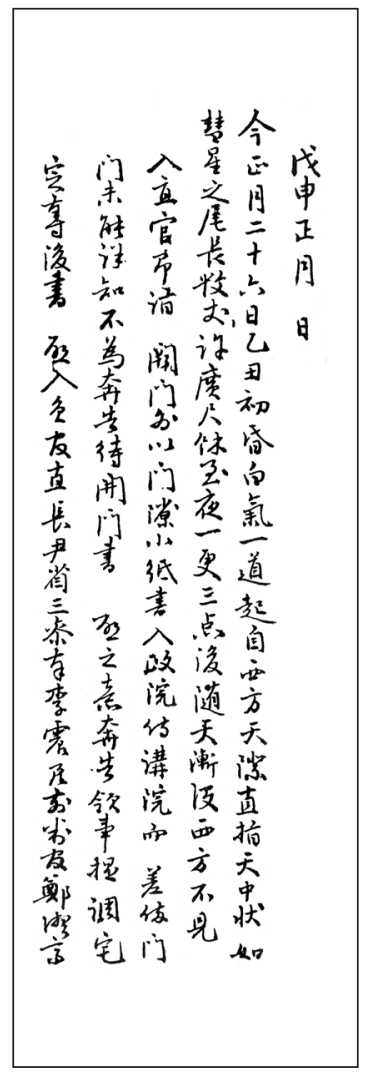

Fig. 2. Page 1 of the 1668 Deungrok (from Korea Meteorological Administration 2012). 


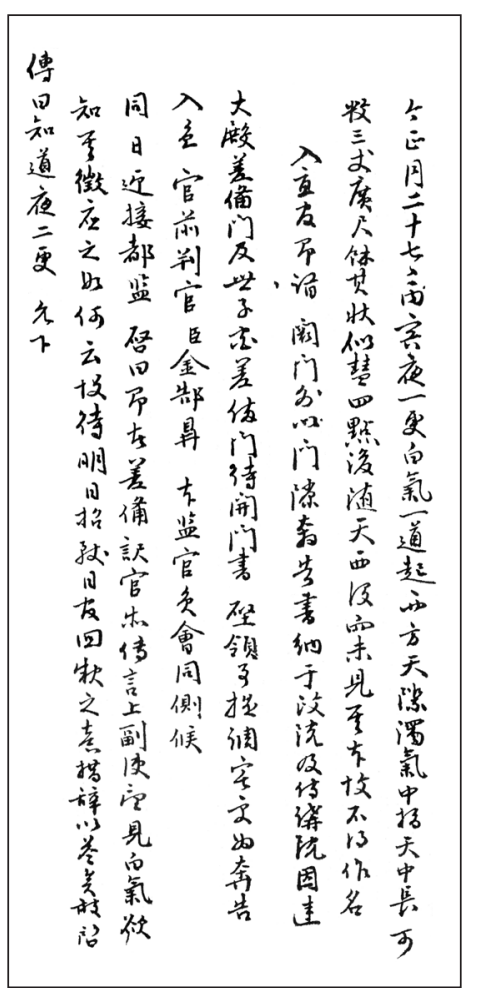

Fig. 3. Page 2 of the 1668 Deungrok (from Korea Meteorological Administration 2012).

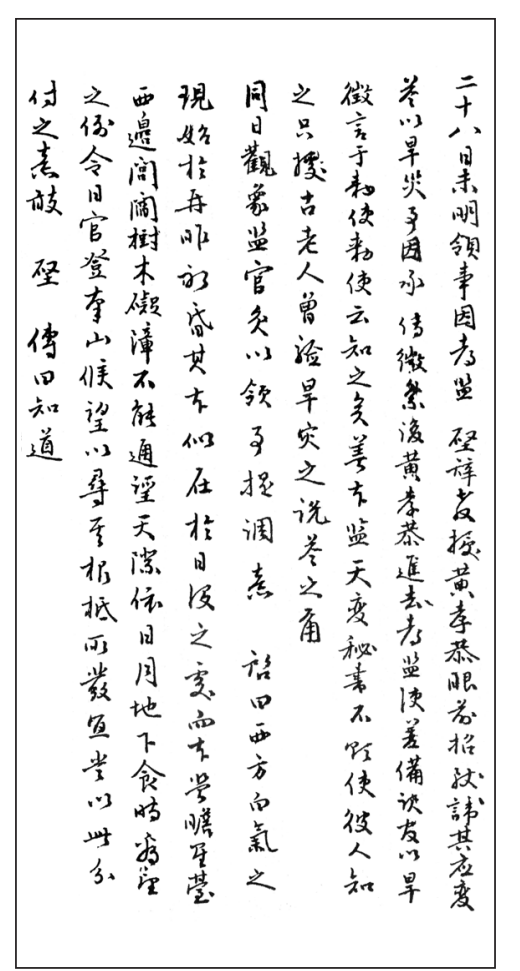

Fig. 4. Page 3 of the 1668 Deungrok (from Korea Meteorological Administration 2012).

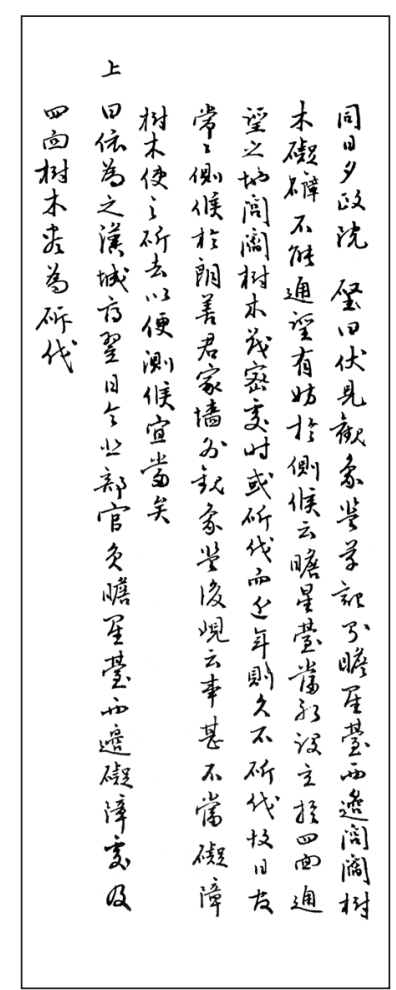

Fig. 5. Page 4 of the 1668 Deungrok (from Korea Meteorological Administration 2012).

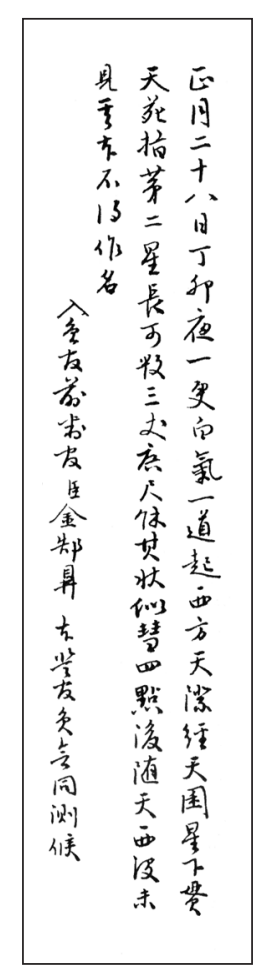

Fig. 6. Page 5 of the 1668 Deungrok (from Korea Meteorological Administration 2012). 


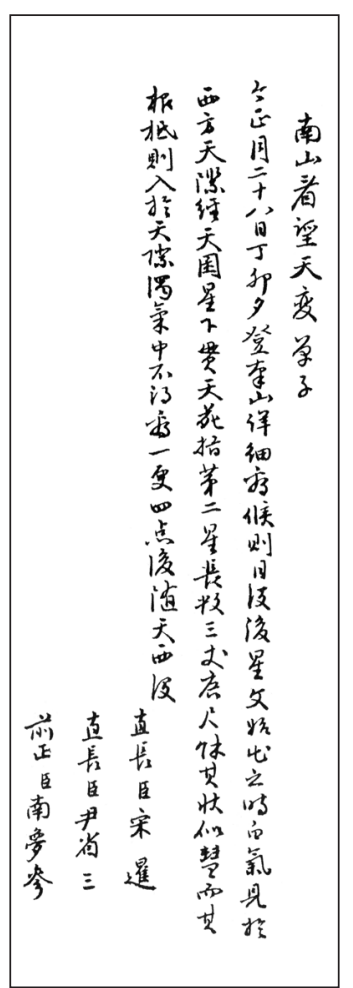

Fig. 7. Page 6 of the 1668 Deungrok (from Korea Meteorological Administration 2012).

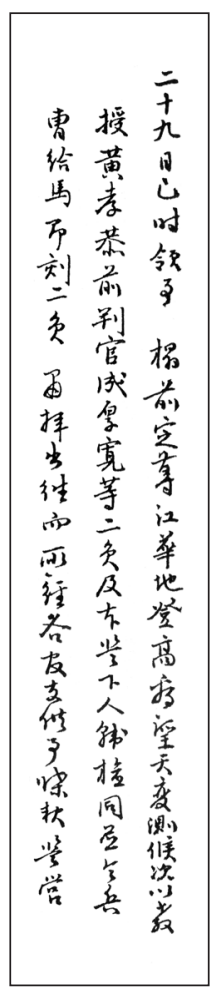

Fig. 8. Page 7 of the 1668 Deungrok (from Korea Meteorological Administration 2012).

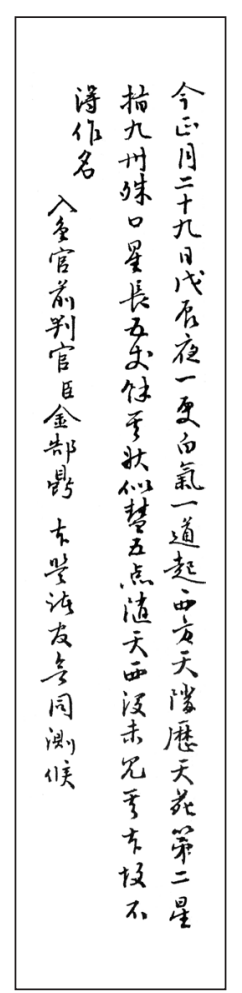

Fig. 9. Page 8 of the 1668 Deungrok (from Korea Meteorological Administration 2012).

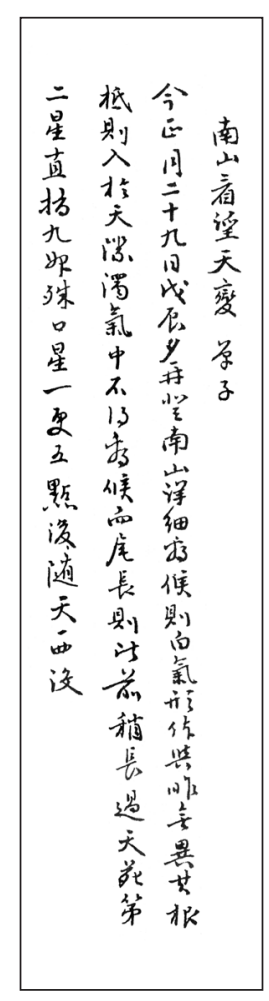

Fig. 10. Page 9 of the 1668 Deungrok (from Korea Meteorological Administration 2012). 


\subsection{Contents of Fig. 2}

戊申正月日

今正月二十六日乙丑初昏白氣一道起自西方天際直指天中狀如 彗星之尾長數丈許廣尺餘至夜一更三點後隨天漸沒西方不見 入直官師詣閶門外以門隙小紙書入政院侍講院而差備門 門未能詳知不爲奔告待開門書啓之意奔告領事提調宅 定奪後書啓入直官直長尹省三參奉李震善前判官鄭德齊

\section{English translation}

On the 26th day, yichou [2], of this first month (of the 9th year of King Hyeonjong) (= 8 March 1668), at the beginning of dusk, one streak of white vapor arose from the western horizon and pointed towards the zenith. Its shape resembled a broom star and its tail was several jang in length and more than a cheok in width. When night came, after the third jeom [= division] of the first gyeong (= night watch), it disappeared in the west following the motion of the sky.

An official on duty deposited an observational report at the gates of the Seungjeong-won and the Sigang-won. When the gates were opened, Hui (a high-ranking official whose full name is currently uncertain) submitted the report to Yeongsa-Jejo (an official of highest rank). Officials on duty were Yoon Seong-sam, Yi Jin-ok and Jeong Deok-je.

\subsection{Contents of Fig. 3}

今正月二十七日丙寅夜一更白氣一道起西方天際濁氣中指天 中長可

數三丈廣尺餘其狀似彗四點後隨天西沒而未見其本故不得作名 入直官師詣閶門外以門隙奔告書納于政院及侍講院因達 大殿差備門及世子宮差供門待開門書啓領事提調宅更爲奔告 入直官前判官臣金郜昇本監官員會同側候

同日迎接都監啓日師者差備譯官等傳言上副使望見白氣欲 知其徵應之如何云故待明日招致日官回報之意措辭以答矣敢啓 傳日知道夜二更允下

\section{English translation}

On the 27th day, bingyin [3], of this first month (of the 9th year of King Hyeonjong) (= 9 March 1668), at night, in the first gyeong, one streak of white vapor arose from the turbid air on the western horizon and pointed towards the zenith. Its length was almost three jang and its width more than a cheok. After the fourth jeom it disappeared in the west following the motion of the sky. Since this type of phenomenon has not yet been seen before, it is impossible to give it a name.

An official on duty deposited an observational report at the gates of the Seungjeong-won and the Sigang-won. When the gates were opened, the report was delivered to YeongsaJejo. The official Kim Go-seong made the observations along with other court observers.

On the same day, Yeongjeob Dogam (an official whose duty was to greet foreign ambassadors), was asked by a high-ranking official of the foreign representatives what kind of portent it could be. Yeongjeob Dogam replied that they should wait until next day and ask the staff of the Court Observatory.

At the second gyeong (20.7-22.9 h), his Royal Highness gave his assent.

\subsection{Contents of Fig. 4}

二十八日未明領事因都監啓辭敎授黃孝恭眼前招致諱 其應変 答以旱災事因承傳微稟後黃孝恭進去都監使差備譯官以旱 徵言于勅使栜使云知之矣差本監天變秘書不欲使彼人知 之只據古老人筸驗早㷋之說答之爾 同日觀象監官員以領事提調意啓日西方白氣之 現始於再昨初昏其本似在於日沒之處而本監瞻星臺 西邊閭閻樹木礙障不能通望天際依日月地下食時看望 之例令日官登南山候望以尋其根抵所發宜當以此分 付之意敢啓傳日知道

English translation

On the 28th day (= 10 March 1668), before dawn, a member of the Observatory staff Whang Hyo-gong was called to His Royal Highness and said that this (phenomenon) was a sign of drought. Whang Hyo-gong suggested addressing the foreign representative after the sacrifice. The foreign representative said that he was aware of it already. The Court Observatory staff expressed the wish that celestial portents should not be divulged to foreigners. The interpretation of this sign was based on the experience of an elderly man.

On the same day, Yeongsa-Jejo Hui said that the white vapor in the western direction appeared two nights ago at the beginning of dusk near the sunset point. However, trees of private houses close to the Observatory made celestial observation difficult. Therefore it was proposed to send observers to the top of Mt. Namsan to make their observation.

His Royal Highness gave his assent.

\subsection{Contents of Fig. 5}

同日夕政院啓日伏見觀象監草記則瞻星臺西邊閭閻樹 木礙障不能通望有妨於側候云瞻星臺當初設立於四面通 望之地閭閻樹木茂密處時或斫伐而近年則久不斫伐故日官 常常側候於朗善君家墙外觀象監後峴云事甚不當礙障 樹木使之斫去以便側候宜當矣 上曰依爲之漢城府翌日令北部官員瞻星臺西邊礙障處及 四面樹木盡爲斫伐 
English translation

In the evening of the same day the Jeongwon (the name of another office) reported to His Royal Highness with reference to a short report which had been received, stating that although the Observatory needed to have a clear view, the nearby trees obscured the view. These trees had not been cut back for several years, so that the observers made their observations at the house of Rangseon-goon (a grandson of King Seonjo). Therefore it was proposed to cut back the trees to facilitate observation.

His Royal Highness gave his approval to the Mayor. Next day, officials of the northern section cut back all the trees surrounding the Observatory.

\subsection{Contents of Fig. 6}

正月二十八日丁卯夜一更白氣一道起西方天際經天困星下貫 天苑指第二星長可數三丈廣尺餘其狀似彗四點後隨天西沒未 見其本不何作名

入直官前判官臣金郜昇本監官員令同測候

English translation

On the 28th day, dingmao [4], of the first month $(=10$ March 1668), at the first gyeong of the night, a streak of white vapor arose from the western horizon. It passed under (the constellation) Cheon-gun and pointed towards the second star of (the constellation) Cheon-won. Its length was about 3 jang and its width more than a cheok. Its shape resembled a broom. After the fourth jeom, following the motion of the sky it set in the west. Since this type of phenomenon has not yet been seen before, it is impossible to give it a name.

The official Kim Go-seong made this observation, together with other court observers.

\subsection{Contents of Fig. 7}

南山看望天變單子

今正月二十八日丁卯夕登南山詳細看候則日沒後星文始出時之 時白氣見於

西方天際經天困星下貫天苑指第二星長可數三丈廣尺餘其狀似 彗而其

根抵則入於天際濁氣中不得看一更四點後隨天西沒

直長臣宋暹

直長臣尹省三

前正臣南夢參

\section{English translation}

Cheonbyeon Danja at Mt. Namsan.

In the evening of the 28th day, dingmao [4], of this first month (= 10 March 1668), from the top of Mt. Namsan, after sunset and beginning with the first appearance of the stars, a white vapor was seen to arise from the western horizon.
It passed under (the constellation) Cheon-gun and pointed towards the second star of (the constellation) Cheon-won. Its length was about 3 jang and its width more than a cheok. Its shape resembled a broom, but its head was invisible because of its location below the turbid horizon. At the fourth jeom of the first gyeong $(20.0 \mathrm{~h})$ it set on the western horizon. Since this type of phenomenon has not yet been seen before, it is impossible to give it a name.

The official Kim Go-seong made this observation, together with other court observers: Song Seom, Yoon Seong-sam, Nam Mong-sam.

\subsection{Contents of Fig. 8}

二十九日巳時領事㛫前定奪汇華地登高看望天變測候次以敎 授黃孝恭前判官成厚寬等二員及本監下人韓檀同站令兵 曹給馬師刻二員肅拜出徃而所經各官支供事牒報監營

\section{English translation}

On the morning of the 29th day (= 11 March 1668), at the double hour si (=9-11 h), the Director of the Observatory ordered two officials, Whang Hyo-gong and Seong Hoogwan, to jointly make observations on the mountain at Gangwha Island; they were to be accompanied by a servant, Han Geom. Now the Ministry of Defence offered horses for the two officials. They were also to be provided with necessities at the local stations on their way.

\subsection{Contents of Fig. 9}

今正月二十九日戊辰夜一更白氣一道起西方天際歷天苑第二星 指九州殊口星長五丈餘其狀似彗五點隨天西沒未見其本故不 得作名

\section{入直官前判官臣金郜昇本監諸官員會同測候}

English translation

On the 29th day, wuchen [5], of this first month (= 11 March 1668), at the first gyeong of the night, a streak of white vapor arose from the western horizon. It passed the second star of (the constellation) Cheon-won, and pointed towards (the constellation) Gujusoogu. Its length was more than 5 jang and its shape resembled a broom. After the fifth jeom it set on the western horizon. Since this type of phenomenon has not yet been seen before, it is impossible to give it a name. The official Kim Go-seong made this observation, together with other court observers.

\subsection{Contents of Fig. 10}

\section{南山看望天變單子}

今正月二十九日戊辰夕再登南山詳細看候則白氣形體與昨無異 其根 抵則入於天際濁氣中不得看候而尾長則比前稍長過天苑第 


\section{二星直指九州殊口星一更五點後隨天西沒}

\section{English translation}

\section{Cheonbyeon Danja at Mt. Namsan}

In the evening of the $29^{\text {th }}$ day, wuchen [5], of this first month (= 11 March 1668), (we) climbed up Mt.Namsan again and made observations. The shape of the white vapor remained the same as on the previous night, but its head was invisible because of its location below the turbid horizon. Its tail became slightly longer and passed the second star of (the constellation) Cheon-won and pointed towards (the constellation) Gujusoogu. After the fifth jeom of the first gyeong it set on the western horizon.

According to the text above, in the first day of observation, the observing staffs of Gwansang-gam named the observed celestial event 'white vapor (白氣),' but they called it a 'comet' at their report since they were not able to figure it out what the white vapor really was. However, they began to regard the white vapor as a strange phenomenon on the next day and then on. If this white vapor had been a comet, there should have been its head, but it was out of sight under the horizon. In their expression at that time, a head of comet was geunjeo(根抵, head). Thus, in search for the head of comet, they made efforts of cutting nearby trees to get better views to the horizon, and climbing up to the Mt. Namsan and even sending observing staffs to Ganghwa Island where the sight to the western horizon is guaranteed. However, they failed to find the head after all and made a conclusion saying "We are not able to name it since there has never been such a phenomenon as this."

In the case that the head of comet is not seen even though its tail is long above the western horizon, the part of head might be located on the other side of the sun. Then, the head of this comet would be observable at the eastern horizon at dawn, instead of in the western sky in the early evening. However, they were not able to find the head in the east at dawn.

What indeed was this white vapor which they could not determine at that time? We introduce here another record from the Annals of Hyeonjong before continuing to the next section.

Jeong Tae-hwa, the prime minister, said secretly, "I heard that the Chinese envoy (北使) had noticed the extraordinary event of white vapor at night and today he was going to ask a staff of our Board of Astronomy about what this event would be an omen of. I am not sure what sign this extraordinary event is, but I suspect that it might be a portent of a war. As we cannot let the Chinese envoy
(北使) know that as it is, it would be better to tell him that it is an omen of famine.", but the king said "I don't think we can hide the fact since they also have astronomers, but it is fine to talk to him based on what you said."

(Annals of Hyeonjong; the $28^{\text {th }}$ day of the $1^{\text {st }}$ month).

\section{WHAT WAS THE WHITE VAPOR IN THE 1668 SEONGBYEON DEUNGROK?}

Wada Yuji (和田雄治) is the first one who mentioned briefly the 1668 Seongbyeon Deungrok. He introduced the celestial event as follows.

Especially in the record of $\left\ulcorner\right.$ The 7th year of Kangxi $i_{\lrcorner}$, "They cut the trees around Cheomseong-dae since the forest was thick and blocked the sight, observed at the summit of Mt. Namsan, and also sent an observing staff to Ganghwa Island for observations." (omitted)

They found it in Europe on March 5 in that year, and it was a comet.

Now we examine the article of this Seongbyeon Deungrok with 9 pages in total.

First, it cannot be a comet or guest star according to the expression in the record. It is because there repeats several times the sentence “而未見其本故不得作名” which means "Since this type of phenomenon has not yet been seen before, it is impossible to give it a name." Among the observing staffs on that occasion, more than a few of them must have participated also in the observations of the great comet in 1664 which is a historical comet having appeared just four years before. And such observers confessed that they could not name it comet or guest star.

Second, it is stated that the tail was as long as five jangs (丈), and such a big comet cannot be imagined (Nha 1981). The greatest comet known so far is the one recorded in The 3rd year of Kangxi (康熙) Cheonbyeon Deungrok (1664), of which the tail was about two jangs (丈) long and 8 or 9 chons ( 寸) wide at its maximum size. The comet in The 24th year of Qianglong (乾隆) Seongbyeong Deungrok (1759)is the famous Comet Halley, and the maximum length of its tail was only two cheoks (尺) which is less than one-tenth of the former one.

Angular sizes (角度) are used in principle for the length or width of a comet, but length units such as jang (丈), cheok (尺), or chon ( 寸) were used in the old literature. Converting those length units to angular sizes in degree (度) was done by Sekiguchi Rigichi (關口鯉吉), and he determined one 
cheok to be about one degree based on his comparison between comet drowings and records on length of tail (尾 長) in several Seongbyeong Deungroks. [Annotation: this conversion is in the paper of Sekiguchi reported to Tenmon Getsubo (天文月報) of the Astronomical Society of Japan in 1910s, which has not yet been found.] Recently Nha (1981) tried another conversion of cheok for lengths of comet tails to angular sizes. Nha used two samples. First, with four photographs of the comet in The 1664 Cheonbyeon Deungrok, he determined about 1.5 degree for one cheok. This is a conversion factor for the 1664 comet in the period of Hyeonjong. With a set of five drawings of the comet in the 24th year of Qianglong (乾隆) Seongbyeong Deungrok (乾隆 二十四年已卯星變謄錄) which was recorded after almost 100 years from that point, however, one cheok was appeared to be 7 or 8 degrees. This is for Comet Halley in the 35th year of Youngjo (1759), but the value derived from those drawings is too large and unrealistic for acceptance. Using the factor of 1.5 degree/cheok, the length in question of <over 5 jangs (5丈餘) > in the record on 'the 29th day of the first month, i.e. March 11, 1668,' is converted into larger than 75 degrees. Then it is too long to be a tail of comet since this length is across almost a half of the sky. With the factor of 7-8 degrees/cheok from the period of Youngjo, it would be 350 to 400 degrees. This value is very unlikely and thus drawings in Deungroks do not represent the true length of comet tails.

Third, what seems even stranger is that the celestial event was expressed as 'white vapor (白氣).' There are some cases of writing color of a comet as 'white' but there is no other record of 'white vapor.' This 'white vapor' is certainly not a guest star. Guest star is a word for nova or supernova, but even the greatest supernova could not be seen as wide spread as in this case. If it is neither a guest star nor a comet, then what is the 'white vapor'?

The position of the 'white vapor' is presented in the Chookhoo Danja on the 28th day of the first month(March 10,1668 ) as 'It passed under (the constellation) Cheon-gun and pointed towards the second star of (the constellation) Cheon-won' according to the observing records at Cheomseong-dae on Mt. Namsan. We draw the 'white vapor' based on its position with respect to the constellations on a star-map. The star-map used here is the Eryue Zhongxing-tu (二月中星図) in Tianwen Tushou (天文圖說) by Yuan Qi (袁 啓) (Yuan 1632). This map was published in the period of the Qing dynasty which is close to the occurrence of the present 'white vapor.'

Another star-map, the Sinbeob Nuju Tongui (Gwansanggam 1789), is known as a meridian star-map in Joseon Dynasty. But this map was not used because it has bright stars only and thus the faint constellations 'Cheon-gun' and 'Cheon-won' are missing in this map. On the other hand, the meridian star-map by Yuan lacks accuracies of the relative positions of the constellations whose shapes were even drawn roughly and arbitrarily. Nevertheless, as is shown in Fig. 11, we draw the 'white vapor' on Yuan's star-map according to the positions from the Deungrok. This position and shape of the 'white vapor' may not represent the real situation, but would be enough to show the phenomenon appearing very close to the horizon on the sky.

Fourth, it is hardly probable, but could we assume that the 'white vapor' was an aurora borealis? As aurora is an atmospheric phenomenon observable around the poles of the earth magnetic field (地球磁氣), i.e. in high latitude regions near to the north pole. Scientifically considered,

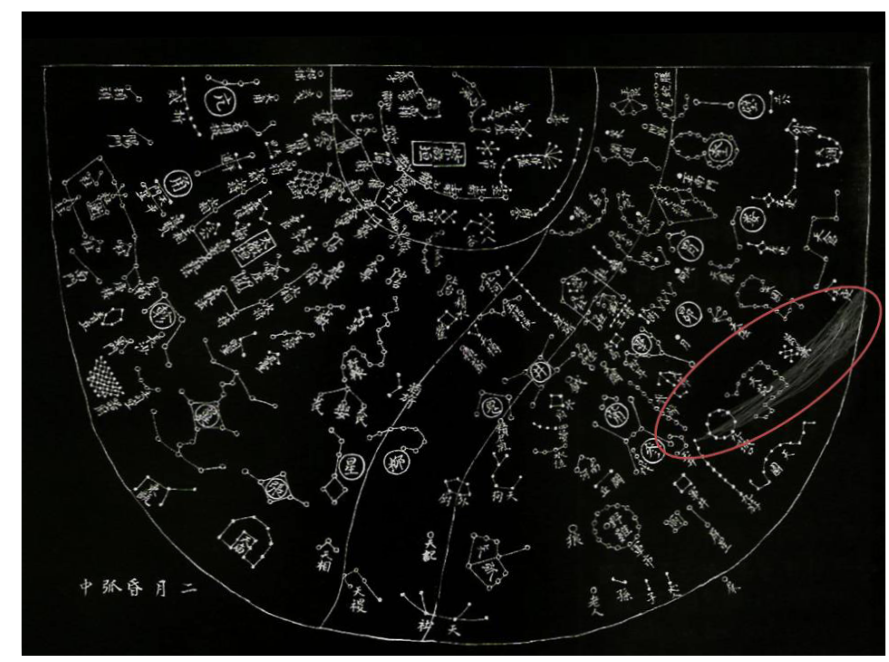

Fig. 11. Location and shape of "white vapor (白氣)" described in the Eryue Zhongxing-tu (二月中星圖) of Yuan Qi (袁啓)'s Tianwen Tushuo (天文圖說). 
aurora is not observable in Hanyang (Seoul) even towards the lowest altitudes to the horizon. Furthermore, the strongest evidence against the assumption of aurora is the record that it was seen towards the western horizon (西方 天際). If the 'white vapor' had been an aurora, it must have been seen towards the northern horizon, but there is no record in the Deungrok to support it. Also it says that the 'white vapor' set in the west over time. Therefore, the 'white vapor' cannot be an aurora at all.

Records of the Deungrok in the possession of Nha last only four days from 26th to 29th of January on the lunar calendar. It may be probable that the original Deungrok does not end at January 29 but continuing on for at least several more days, and the later parts should have excluded from the copy-making. When they close a series of each celestial event, it was a customary practice of Gwansang-gam in Joseon to state that the event had been concluded and to list at the end of the Deungrok all names of the observing staffs participated. Unfortunately this important part is missing in the copies of Nha.

\section{EXAMINATIONS AND NEW FACTS}

Lynn (1882) re-examined several observing reports available in Europe on this 'celestial event'. The observations were performed in 1668 in various places such as Lisbon, Cape of Good Hope, Goa, San Salvador, etc., but in his brief report, Lynn paid more attention to the observational record by Father Valentin Estancel (1674) at San Salvador. Some parts of Lynn's article are introduced here as follows.

\footnotetext{
"The comet was observed for a few days, commencing on the 5th of March. He saw it in the evening, and was surprised to find it of extraordinary brightness when first seen, and then decreasing, instead of becoming brighter by degrees as he had noticed in other comets. As to the color of this comet, it was at first very splendid, but the brightness lasted only for three days, after which it did considerably decay. But that which seemed somewhat strange was, that having lost so much of its light, yet its bulk was diminished, but continued rather increasing until the comet disappeared."
}

Lynn followed up with that the perihelion distance of this comet was reported by Henderson to be $0.25113 \mathrm{AU}$. Considering that the perihelion distance of Mercury is 0.307 $\mathrm{AU}$, this comet entered into the orbit of Mercury. There is another supporting article, and according to this No details were provided, but later orbits indicated the comet was then in Cetus and it was probable that only the tail was seen. The comet had passed only $1^{\circ} .5$ from the sun on February 29. --------- Giovanni Cassini obtained his first observation on the 10th $(=28$ th day of the first month) during the first hour of the night and saw a "path of light" which he presumed was a comet, extending from Cetus through Eridanus. The tip of the tail lay near 14 Eridani, while the head was either hidden by "horizontal clouds" or still below the horizon.

(http://cometography.com/lcomets/1668e1.html)

The above statement, 'he presumed was a comet', is indeed a sentence by Cassini who left his mark on the history of astronomy as an excellent observer. And the statement 'the head was either hidden by "horizontal clouds" or still below the horizon' is completely consistent with the record by Gwansang-gam on 10th and 11th of March. With an insight on the situation, Lynn made a conclusion at the end of his article introduced above as "Any attempt to identify the comets of (omitted) with that of 1668 can be but of little weight." This shows well that this 'celestial event' was regarded as extraordinary also in Europe. Considering those opinions together, we understand better the difficulties that the observing staffs at Gwansang-gam had at that time.

Also in China, there are records of celestial events written in a period close to the occurrence of the 'white vapor.' Here we count dates on the solar calendar. First, there is a record on a comet from January 14 to February 11 in 1668 (Beijing Observatory 1989a), but this has nothing to do with the 'celestial event' in question. The second record was made after about one month, on March 2, 1668. It says 'A comet appeared at night in the west. The length of its tail was a few jangs, and it disappeared after several days' (Beijing Observatory 1989b). This is clearly a record of comet. However, also in China, there are more than a few dozens of observing records on 'white vapor' and 'black vapor (黑氣)' during the same period. The first one on March 3 says 'Vapor appeared in the west, which was red then looked white. The bottom of it was 'black vapor' and its shape is similar to a cloth (布)' (Beijing Observatory 1989c). After this record, there are a number of records from March 6 using only the term 'white vapor.' Two examples are as follows. '(March 6): White vapor appeared with a shape like white silk (煉), which passed through the southwest and pointed straight to the northeast' (Beijing Observatory 1989c) or '(March 7): White vapor like a spear (槍) appeared in the west at the 19th of the 24 periods of the day, and black vapor like a sword (刀) with three blades appeared at the night of 27th day' (Beijing Observatory 1989d). Such Chinese records are 
interesting, but on the other hand, are difficult to interpret since they did not describe the shapes and positions scientifically, not like the records by the observing staffs at Gwansang-gam of Joseon.

Now we return to the records in Joseon. In addition to the Deungrok, there are other records on the 'white vapor' also in Hyeonjong Sillok (顯宗實錄) and Seungjeong-won Ilgi (承 政院日記). Among those records, the following three records in Seungjeong-won Ilgi should need new attentions.

1) On the 4th and 5th days of the second month in the 9th year of Hyeonjong, the expression of chiugi (虫尤旗)' was used. This is an expression for a comet splitting into two tails.

2) On the 4th day of the second month in the 9th year of Hyeonjong, an unbelievable tail of 7 jangs long, which was longer than 5 jangs in the Deungrok, was observed.

3) On the 5th day of the second month in the 9th year of Hyeonjong and several days afterward, a 'light' was introduced as 'vapor like fire light (有氣如火光).

Except for 1) above, those records are against the assumption of comet. Therefore, it is clear that the 1668 celestial event is a new sample for studies on the solar activity and abnormal phenomena of the earth atmosphere. It might be such an important discovery in the ancient observing records in China, Korea, and Japan as the facts that sunspots were observed with the unaided eye and that guest stars were supernovae which made significant impacts on modern science.

As briefly mentioned earlier, there is an interesting article in the Deungrok on the 28th day of the first month in the 9th; '---stating that although the Cheomseong-dae needed to have a clear view, the nearby trees obscured the view. These trees had not been cut back for several years, so that the observers made their observations at the house of Rangseon-goon.' We became aware from this article that the observing site in Hanyang at that time was North Gwangwha-bang (北部廣化坊) which is to the west of the main gate of the Changdeok Palace and in front of the current office building of $<$ Hyundai Engineering and Construction>. This observing site was named Gwancheondae (觀天臺) in 1983, about 30 years ago by Jeon \& Nha (1983). However, this place should now be rightly called Cheomseong-dae in North Gwangwha-bang (北部廣化坊瞻 星臺) since the old name was given without clear references at that time. At the same time, also the name of Gwancheondae in the Changgyeong Palace should be corrected to be Cheomseong-dae. Rangseon-goon (朗善君) is a grandson of King Seonjo and was famous as a writer. The location of
Table 2. Names of the 12 Chookhoo-gwan (測候官，astronomers).

\begin{tabular}{|c|c|}
\hline Deungrok & $\begin{array}{l}\text { Kim Go-seung (金郜昇), Nam Mong-sam (南夢參), } \\
\text { Seong Hoo-gwan (成厚寬), } \\
\text { Song Seom (宋暹), Yoon Seong-sam (尹省三), } \\
\text { Yi Jin-seon (李震善), } \\
\text { Jeong Deok-je (鄭德齊), Whang Hyo-gong (黃孝恭) }\end{array}$ \\
\hline $\begin{array}{l}\text { Seungjeong } \\
\text {-won Ilgi }\end{array}$ & $\begin{array}{l}\text { Kim Man-gi (金萬基), Kim Si-jin (金始振), } \\
\text { Shin Hoo-jae (申厚載), An Myeong-no (安命老) }\end{array}$ \\
\hline
\end{tabular}

Cheomseong-dae is now clear considering that he lived in this North Gwangwha-bang.

The recovery of the 12 observing staffs in total is also a significant result. Among them, 8 were found in the Deungrok and 4 in Seungjeong-won Ilgi, whose titles and names are listed in Table 2. It would be one of future work to determine who were participated in the comet observation four years before, the 5th year of Hyeonjong.

\section{ACKNOWLEDGMENTS}

This work was funded by the Korea Meteorological Administration Research and Development Program under Grant RACS_2011-4016. We wish to express our sincere appreciation to Professor Richard Stephenson of University of Durham and Dr. Youngsin Chun of National Institute of Meteorological Research for their valuable advices and suggestions during the course of this research. The authors also gratefully acknowledge two anonymous referees.

\section{REFERENCES}

Beijing Observatory, Anhuisheng Shidaixuan-zhi, 2, 19, Zhongguo gudai tianxiang jiluzongji, 471 (1988a).

Beijing Observatory, Guangdongsheng Chaozhoufu-shi, 11, 30, Zhongguo gudai tianxiang jiluzongji, 471 (1988b).

Beijing Observatory, Hubeisheng Dongyangsheng-zhi, 1, 38, Zhongguo gudai tianxiang jiluzongji, 471 (1988c).

Beijing Observatory, GuangxishengQinzhou-zhi, 10, 19, Zhongguo gudai tianxiang jiluzongji, 471 (1988d). Gwansang-gam (觀象監), SinbeobNujuTongui (新法漏籌通義) (1789).

Jeon S-W, Nha I-S, On the Gwansang-gam Gwancheon-dae, Dongbang Hakji, 40, 251-267 (1983).

Korea Meteorological Administration, Restoration of chugugi records from the North Korean region and translation of the Annals of the Joseon Dynasty, 2, 949-971 (2012).

Lynn WT, The comet of 1668", Observatory, 5, 329-331 (1882). 
Nha I-S, Gwansang-gam and modern astronomy: Seongbyeon Choohoo Danja, Dongbang Hakji, 20, 209-232 (1978).

Nha I-S, Comet records in the Youngjo and Jeongjo reigns of Korea, Dongbang Hakji, 29, 193-239 (1981).

Nha I-S, Seongbyeon and Gaekseong Deungroks preserved in the Yonsei University Library, Dongbang Hakji, 34, 207-247 (1982).

Nha I-S, Seongbyeon Chookhoo Danjas of Joseon Gwansanggam, Baekje Yeongu, 17, 215-229 (1986).

Rufus WC, Astronomy in Korea, Transactions of the Korea Branch of the Royal Asiatic Society, 26, 39-40 (1936).

Seong JD, Beongyu and Cheukhoo, Seoungwan-ji, 1-2, 376386 (1818).

Valentin Estancel P, Observations concerning the comet that was seen in Brasil, An. 1668, RSPT, 9, 91-93 (1674).

Wada Y, Seihen Sokko Dansi, Chosen Kodai Kansoku Kiroku Chosa Hokoku, Observatory of Chosen Government General, 173-176 (1917).

Yuan Q, Tianwen Tushuo, Xusiu Sikuquanshu, 1031, 497522 (1632). 